\title{
BLACK AND WHITE AUSTRALIA, 1770-1970. A HISTORY OF DISPOSSESSION ${ }^{1}$
}

POR

\author{
EMANUELA APPETITI
}

\begin{abstract}
El propósito de este artículo es estudiar el contacto/impacto que tuvo lugar en Australia entre aborígenes y europeos, generado por la llegada de la Primera Flota Británica en 1770 y la posterior colonización europea de esas tierras. El trabajo se centra en las actitudes cambiantes de los Australianos blancos con respecto a los aborígenes, que pasaron desde la violencia inicial al principio de la colonización, al paternalismo y sentimientos protectores que caracterizaron los primeros años del siglo XX. Finalmente se analiza la política de asimilación e integración forzosa asumida en el período que se extiende entre las décadas del 40 y el 70 de este siglo.
\end{abstract}

Before the coming of the White man, the Aborigines were the sole population to live in and exploit the huge Australian continent. It is estimated that they have lived there for at least 60.000 years $^{2}$, although recent archaeological investigations estimate that they have inhabited the continent for 100.000 years. At the time of the first contacts, in the 18th century, they were about $300.000^{3}$, divided into groups, which the Europeans would later call «tribes». As hunter-gatherers, they moved through their own group's territories, according to the seasons, carrying with them only the necessary for hunting and gathering. They had begun to develop agriculture, but had not domesticated animals. Their technology was

1 The decision to focus this analysis on the Australian situation from the colonization up to the 1970's is based on the fact that, on 27 May 1967, the Constitution Alteration (Aboriginals) Referendum passed. This Referendum proved to be a turning-point in Aboriginal advancement. Black and White Australians faced new situations and, accordingly, developed new strategies to deal with them, which will not be discussed in the present paper.

2 See T. GRIFFITHS, Hunters and Collectors. The Antiquarian Imagination in Australia (Studies in Australian history), Cambridge University Press, Cambridge, 1996. On Aboriginal occupation of Australia, see p. 309, note 34.

3 H.P. SCHAPPER, Aboriginal Advancement to Integration. Conditions and Plans for Western Australia (Aborigines in Australian Society, 5), Australian National University Press, Canberra, 1970, p. 3 
in perfect harmony with nature, and their spiritual affiliation with land was profound. Although material life was simple, the cultural one was, and still is, rich and complex, based on the ancestral beings and heroes of the Dreamtime ${ }^{4}$, who travelled through the land and gave it the present shape, besides creating all the living things and then resting for ever in the rocks, waterholes, rivers which are regarded, therefore, as sacred sites. Aborigines belong to the land and, accordingly, the land is the source of life, both material and spiritual, because the relationship between man, place and supernatural beings is timeless, beginning before birth and continuing after death ${ }^{5}$. Taking away the land from the Aborigines does not only mean depriving them of the opportunity to continue to hunt and gather food, but above all it means that the places identified as part of themselves do not belong to them anymore, that tribal laws, myths and rites related to these places cannot be transmitted from the elders to the younger generations, and that ceremonies cannot be practiced there anymore, in short: the society loses its organisation and order. From what we have said, we can easily imagine that, with the coming of the Europeans, life for the Aboriginal peoples was never to be the same again.

\section{THE FIRST CONTACT}

Captain James Cook (1728-1779) landed in April 1770 in Botany Bay (named so for its variety of botanic specimens) and, after having sailed for a further $3.000 \mathrm{~km}$ to the north, he raised the British flag and took possession of the continent, on behalf of King George III (1738-1820). No attempt was made by Britain to colonise it, until the loss of American colonies in the American War of Independence (1776-1783) raised the need for alternative overseas settlements to relieve British overcrowded prisons: this huge, far island, best suited this need. In January 1788, Captain Arthur Phillip (1738-1814) reached Botany Bay with his crew of convicts, but due to the openness of this bay he moved a few kilometres north, to Port Jackson (where Sydney now stands), and settled definitely in Australia. The British regarded Australia as Terra Nullius, viz no-one's land, since, at

4 Dreamtime or Dreaming are English words, now widely accepted, which refer to the complex whole of Aboriginal traditional beliefs and spiritual concepts, called in some Indigenous languages Alcheringa, Tjugurpa, Gulal or Wongar. On this subject, see, for example, W.E.H. STANNER, On Aboriginal Religion (Oceania Monograph, 11), University of Sydney, Sydney, 1963, with a facsimile edition in 1989 (= Oceania Monograph, 36), and, by the same author, «The Dreaming», in T.A.G. Hungerford (ed), Australian Signposts, F. W. Cheschire, Melbourne, 1956 (reprinted in W.H. STEWARDS (ed), Traditional Aboriginal Society, Macmillan, Melbourne, 1987, pp. 225-236).

5 Two thorough and classical studies on Aboriginal Culture before European contact are A.P. Elkin, The Australian Aborigines. How to understand them, Angus \& Robertson, London \& Sydney, 1938 (reprint: 1954), with a revised edition in 1974, and R.M. \& C.H. BERNDT, The World of tbe First Australians, Ure Smith, Sydney, 1964 (second edition: 1977).

R. I., $1999, \mathrm{n}^{\circ} 217$ 
least apparently, it did not belong to anyone. To their eyes, it was an unsettled land, with no sign of exploitation (not agricultural or pastoral, or other), there were no geographical limits, borders, frontiers, settlements, in sum: it did not present any of the normal Western requirements to define it as a State ${ }^{6}$. The first contacts with the Indigenous inhabitants confirmed this first impression and Phillip did not immediately recognize that Aboriginal people were the real and sole owners of this continent ${ }^{7}$. Aboriginal semi-nomadic life, the absence of proper settlements and of a visible tribal hierarchy, such as a war class or a recognized chief and, first and foremost, a different concept of land property, contributed to strengthen this impression and gave rise to the gap between Black and White Australia, a gap which still remains to be filled ${ }^{8}$.

Captain Phillip, the first Governor and Administrator, was instructed, according to the best British tradition in matters of colonisation, to mantain good relations with and to reconcile the native inhabitants, who were considered as British subjects and, therefore, to be treated with respect. But, in spite of the good intentions of the first administrators, it soon became clear that expropriation of land went together with resistance.

Although Aborigines had already had contacts with other peoples, like the Macassan trepang fishermen coming from the North, they never faced a situation of permanent confrontation with another culture. Unlike the Macassans, who came from time to time to fish and exchange tools and ornaments with the Abo-

6 N.B. Tindale, Aboriginal Tribes of Australia. Their Terrain, Environmental Controls, Distribution, Limits, and Proper Names, University of California Press, Berkeley, Los Angeles, London, 1974, 2 vols, and -more recently- S.L. DAVIS \& J.R.V. PRESCOTT, Aboriginal Frontiers and Bounderies in Australia, Melbourne University Press, Melbourne, 1992, give an opposing view.

7 See «15 May 1788, Governor Phillip's first dispatch», in S. N. STONE, Aborigines in White Australia. A Documentary History of the Attitudes affecting Official Policy and the Australian Aborigine, 1697-1973. Selected and Edited by ... Heinemann Educational Books, South Yarra \& London, 1974, p. 19: «When I first landed in Botany Bay the natives appeared on the beach, and were easily persuaded to receive what was offered them, and, tho' they came armed, very readily returned the confidence I placed in them by going to them alone and unarmed, most of them laying down their spears when desired ... They were all naked, but seemed fond of ornaments, putting the beads or red baize that were given them round their heads and necks ...»

For a full account of this travel, see: The Voyage of Governor Phillip to Botany Bay with contributions by other officers of the First Fleet and observations on affairs of the time by Lord Auckland (Originally published in 1789 as the official account of the expedition to New South Wales and the founding of Australian Settlement), with an Introduction and Annotations by J.J. Auchmuty, F.A.H.A., Angus \& Robertson in Association with the Royal Australian Historical Society, London, Melbourne, Singapore, 1970.

8 On the differences between Aboriginal and European concepts of property, see: $\mathrm{N}$. WILliams, The Yolngu and their Land: A System of Land Tenure and the Fight for its Recognition, Australian Institute for Aboriginal Studies, Canberra, 1986; especially chap. 7: «The uses of history: early accounts of hunting and gathering» (pp. 109-125); chap. 8: «Colonies and the uses of history» (pp. 126-138); and chap. 9: «Aboriginal Land in Australian perspective» (pp. 139-156), where this subject is carefully studied in its multifold aspects. 
rigines, Europeans moved to Australia to settle in, to stay forever. When European settlements expanded far beyond the original settlements of convicts and occupied tribal lands, fights and clashes between the two cultures became more and more frequent (the Aborigines attempting to drive off the cattle on pastoral stations, the Whites shooting at them), leading, as we shall see, to the almost total annihilation of some groups of Aborigines, who were regarded as a «dying race» until as late as 1937 .

\section{COLONISATION}

The settlers arriving after 1793 started to produce wool through the breeding of Spanish merinos sheep. The squatters - people who settled land without official approval- gained more and more political and economical importance and in 1846 obtained the right to settle the pastoral lands in the most internal parts of the continent. Indigenous people rarely succeeded in preventing these expropriations and, even worse, their attempts generated ferocious retaliations. As for Tasmania, the original inhabitants were massacred by the most dangerous convicts (who were transferred from the continent to this island in order to be kept under a stricter control), as well as by the white stock-keepers. It seems that in 1838 the survivors were about eighty, by 1843 they numbered about fifty. In this context, it is not surprising that the only descendants of the Tasmanians have come from the unions of Tasmanian women with sealers, living on islands in Bass Strait, such as Flinders Island or the tiny Gun Carriage Island ${ }^{10}$.

To the Pastoral and Cattle Industry, we have to add a further mean of exploitation of land, the mining operations, which started in 1851, when an Australian coming back from California, certain Mr. Edward Hargraves, discovered a little quantity of gold in the area of Bathurst (New South Wales), which had the effect of attracting more and more people. Over these two centuries, the mining industry has reached a major importance in the Australian economy, thanks to the rich deposits of gold, opals and uranium as well as crude oil fields, iron, coal and aluminium mines scattered mainly in the arid central and northwestern areas of the continent and, quite often, under Aboriginal sacred lands ${ }^{11}$.

9 C.D. Rowley, The Destruction of Aboriginal Society, (Aboriginal Policy and Practice, vol.I), (Aborigines in Australian Society, 4), Australian National University Press, Canberra, 1970, p. 286. On the concept of «Dying Race or fast disappearing», see also: SCHAPPER, Aboriginal Advancement to Integration ... [3], p. 21, and the article «Aborigines. A Dying Race. Grave Charges Laid Against the Whites», article's title on The Sydney Morning Herald, 4 May 1927, p. 10 (in STONE, Aborigines in White Australia ... [7], p. 153).

10 RowLEY, The Destrucction of Aboriginal Society [9], pp. 43-53.

11 The problems generated by the mining industry are of special complexity because mineral activity involves, by definition, drilling. Now, when this has to be done on Aboriginal sacred land, 
Australia of the 19th century is characterized by the extension and the organisation of the separate colonies and the development of the first cities. Violence excerted over the Aborigines is strong at this time: exploited in cattle and pastoral stations, often enchained, moved from one station to another, or to special gaols, they enjoy no rights at all. Dispossession of land, exclusion and segregation shaped the common policies adopted by White Australians towards the Indigenous inhabitants during almost the whole of the first century of settlement.

The several reports of that time state the semi-starvation conditions lived by the Aborigines: they received just blankets to protect themselves from the cold nights, and poor food, like tea, sugar and flour ${ }^{12}$, which, together with the immobility, the new introduced diseases such as syphilis and serious pulmonary diseases, and the strong use of alcohol, destroyed them physically, while the complete loss of control of the land, the impossibility to look after the secret-sacred places (occupied now by white settlements) and the prostitution as a mean to get alcohol, contributed largely to the disruption of the traditional life. There were also the frequent cases of poisoning ${ }^{13}$, and a horrible way of «dispersing» them ${ }^{14}$, both

where totemic spirits live (and/or also those of the dead people if they are burial sites), the consequences can be disastrous for Aborigines who belong to that sacred land. Furthermore, the first mining agreements were normally negotiated between Government and companies, without consulting Aboriginal people, who now ask, therefore, to re-negotiate them. See, among others, P.H. Rogers, The Industrialists and the Aborigines. A Study of Aboriginal Employment in the Australian Mining Industry, Angus \& Robertson, Sydney, London, Singapore, 1973; R. HowITT \& J. Douglas, Aborigines and mining companies in Northern Australia, Alternative Publishing Cooperative (APCOL), Chippendale, 1983.

On the Aboriginal struggle against mining operations, and as an example, see the article «Noonkanbah», by S. HAWKE \& M. DOYLE, in Identity, vol. 4, No 1, pp. 7-9 (Woden, 1980), about the struggle to stop an oil company from drilling on a «goanna» dreaming place, sacred to the Yungngora community, at Noonkanbah (Western Australia). For a deeper knowledge of this subject, see: S. HAWKE \& M. GALlaGHER, Noonkanbah. Whose Land, Whose Law, Fremantle Arts Centre Press, Fremantle, 1989.

12 It is difficult refraining from comparing their traditional diet as hunter-gatherers, rich in proteins, vegetable and fruits, with the new one, certainly not adequate to ensure a healthy life...

13 A..On the Kilcoy Station, owned by Mr. Evan McKenzie, there were two white men killed, and an imported bull; and their retaliation was very severe on the blacks - they destroyed hundreds of them. -In what way? By shooting and poisoning them. -What with ? With strychnine and arsenic, in flour»; «Royal Commission into Native Police Force, 14 May 1861, Captain John Coley's evidence», in STONE, Aborigines in White Australia... [7], pp. 78-80 (the extract appears at p. 79).

14 «..Do those troopers understand English sufficiently to comprehend your orders? Oh, yes ... What was the nature of those orders? I told them to surround that camp of Telarnon blacks, and to disperse them. What do you mean by dispersing? Firing at them ... I wish to know what induced you to give those orders? The letters I had received from several squatters, complaining that the blacks were robbing their huts, threatening their lives, and spearing their cattle and sheep ... After this affair at Dugandan where did you go? I went to Fassifern, following up the same track ... I found a small camp of blacks, and dispersed them ...»; «Royal Commission into Native Police Force, 9 May 1861, Lieutenant Wheeler's evidence», in STONE, Aborigines in White Australia... [7], pp. 75-78 (the extract is at p. 77). 
easy and quick ways to eliminate them. The original population was drastically reduced: for instance, around Adelaide (South Australia), it declined from 650 in 1841 to 180 people in $1856^{15}$.

Unknown to the Aboriginal people was the fact that, administratively speaking, they were considered as British subjects by the local Governors, who applied to them, with brutal effect, the British law. On their side, the Aborigines had not the slightest idea of what «Great Britain» was, therefore they did not understand or take any notice of these attempts. Finally, the linguistic problem prevented efforts to reach an understanding. Special protection laws were introduced and, at different times in all the states, Boards and Commissions were established by the end of 19th century, such as the Port Phillip Protectorate, established in New South Wales in 1838, the Board for the Protection of Aborigines in Victoria (1869), or the Western Australian Aborigines Protection Board (1886).

\section{PROTECTION POLICY: SETTING UP MISSIONS, HOSTELS, RESERVES}

It is in this difficult context that missions, hostels and reserves were set up. In fact, in 1837, the Select Committee on Aborigines, a special branch of the British House of Commons, decided to send missionaries to Australia, officially to protect, civilise, and Christianise the natives, which meant, in fact, to discriminate and segregate them. This policy matched well the growing' general sense of paternalism and the feeling that something had to be done to save this «dying race». Protection attitudes prevailed, although open fights and clashes would continue for a long time to come. Over the years, numerous missions, run mainly by Presbyterians, Catholics, Anglicans and Lutherans, were set up in most States, but primarily in the so-called Outback (the remotest areas), where contact with the White had been occasional, like the mission run by the Lutherans at Cape Bedford and the other one of the Presbyterians at Mapoons, both in Queensland. Some of them had a short life and closed after a short while (with the consequent moving of the Aborigines who lived there, on the Government reserves), others were enlarged to host a growing number of people, regardless of the fact that they belonged to different tribes. Thereupon, problems of relation and conflicts among them arose. The missions aimed at teaching English to the natives mainly by means of the Bible, providing them with land to go hunting and training them in working. The missions set up along the west and northern coasts engaged Indigenous people in pearls and fishing industry, which Torres Strait Islanders and

15 Rowley, The Destruction of Aboriginal Society [9], p. 203. From the about 300,000 people in 1788 , Aboriginals passed to 67,000 in 1901 and twenty years after they were reduced to little more than 60,000. Only around the 1950's, Aboriginal population became to increase again. See F. LANCASTER JONES, The Structure and Growth of Australia's Aboriginal Population (Aborigines in Australian Society, 1), Australian National University Press, Canberra, 1970, Table 1, p. 4.

R. I., $1999, \mathrm{n}^{\circ} 217$ 
some Aborigines did not dislike, probably because they were already a seafaring people who lived mainly on the product of the seas. Results were different, depending mainly on the reaction of the Aborigines to adapt themselves to a sedentary life and to accept this new condition as employees, but, generally speaking, the missions had little success.

Quite different was the development of the missions established in Arnhem Land (Northern Territory), where traditional inhabitants had had little if any contact with the Europeans, and still lived a traditional life. At the beginning, only food and clothes were provided to Aborigines, there were no schools, and staff was limited to few people, but over the years they incredibly increased in population as well as in staff, and remained a major contributor in the shaping of the Northern Territory.

Apart from the perpetual attempt to replace traditional beliefs (and practices such as initiation rites and other rituals) with the official religion they represented, the main purpose of the missions was to protect the natives from alcohol, which became by far the principal cause of their physical destruction and therefore was banned from the missions from the very beginning ${ }^{16}$. The use of alcohol had, and still has, disastrous effects on their health, and it has led to men leaving their tribal groups to go to the cities, ready to accept any kind of work to get cheap liquor in exchange. As for the women, some prostituted themselves in order to obtain liquor, food, tobacco and cloths. The hope of achieving a European style of life, which some highly desired, also played an important role in this matter. As a consequence, some women began to neglect traditional life, often leaving their families to live with white men and to procreate with them.

To further make this situation worse, if at all possible, abductions and sexual exploitations of Aboriginal women by the European settlers were frequent in the areas closer to the stations, and this spread syphilis and other venereal diseases among the Aborigines.

The Report by Mr. Paul Foelsche, an Inspector of Police in South Australia written in 1899 at the request of the Government Resident, Mr. Justice Dashwood, relates the living conditions of the Aboriginal people of that State, during the period between 1882 and 1899. Among others, he stated that:

Outside the boundaries of the more settled districts, ie., pastoral settlements, a different state of relation exists between the Europeans employed on the stations and the aborigines; in many instances boys who assist in station

16 J.P.M. LONG, Aboriginal Settlements. A Survey of Institutional Communities in Eastern Australia (Aborigines in Australian Society, 3), Australian National University Press, Canberra, 1970 , p. 141. On the devastating effects of alcohol on Aborigines' health, and the changing policy on this matter, see more recently: M. LEWIS, A Rum State. Alcohol and State Policy in Australia 1788-1988, Australian Government Publishing Service, Canberra, 1992, chap. 7: «The State, alcohol and Aborigines», pp. 152-172. 
work were, and perhaps are still, obtained by what is termed «running them down», and forcibly taking them from tribes to stations some distance away from the tribe, and young girls were and, I believe, are still obtained in a similar manner ... and against the will of her relatives... ${ }^{17}$.

And this was commonplace in the other Australian states as well. By voluntary or forced sexual intercourse with Europeans, they gave birth to half-castes or part-Aborigines, destined to become the «big problem» for government bureaucrats and White Australians who refused to accept their Aboriginality.

Aborigines could no longer be ignored. The imperative became saving the «race» from extinction. But special laws of protection and assimilation must apply to special subjects, who need to be defined in a legal, official way. Hence the definitions of full-blood and half-caste Aborigines, definitions which changed over the years until recent times, in legislation and on the occasion of every census, and which falsely determined the Aboriginal population, as well as its distribution throughout the continent ${ }^{18}$.

Creating a definition of Aboriginal, full-blood and half-caste, was not so easy; moreover, each State generated its own, independently from the other States. This meant that a person might be referred to as Aboriginal in one State, but not in another. However different these definitions, they showed a common need to distinguish a part of the population from the rest, which in itself revealed a discriminative attitude.

As an example, we can quote some of the very first definitions. The one given in the Western Australia Aborigines Protection Act (1886), included every Aboriginal Native of Australia «and every Aboriginal half-caste or child of a half-caste, such half-caste or child habitually associating and living with Abori-

17 «1899. Mr. Paul Foelsche's report», STONE, Aborigines in White Australia... [7], pp. 114117 (see p.115 for the extract quoted).

18 Special definitions such as full-blood, half-caste (or mixed-blood or part-Aborigine), and even the less common octoroons and quadroons, stated, according to the law of that epoch, the «level» of Aboriginality of a person, from totally black (both father and mother Aboriginal) to mixed-blood or part-Aborigine (often referring to mother black and father white, this stressing the point that the opposite was just not possible), to lighter portions of Aboriginal strain, such as $1 / 4$ or $1 / 8$ of Aboriginal blood. Although these definitions disappeared over the years, still it is historically important to record them, because they testify to the official Australian attitudes towards Indigenous Australians. I have based this part of the article mainly on RowLEY, The Destruction of Aboriginal Society [9], Appendix A: «Who is an Aboriginal? The answer in 1967» (pp. 341-364), and Appendix B: «The Aboriginal population» (pp. 365-398), and on LANCASTER JONES, The Structure and Growth ... [14].

About crossbreeds in general and strategies to be followed with octoroons and quadroons, see the report written in 1928 by J.W. Bleakley, Chief Protector of Aborigines in Queensland, on fullblood and half-caste Aborigines in Northern and Central Australia, in STONE, Aborigines in White Australia [7], pp. 154-166. 
ginals» ${ }^{19}$. Similarly, the Queensland law at the end of the century defined a halfcaste as «the offspring of an aboriginal mother and other than an aboriginal father ${ }^{20}$. The Northern Territory Aboriginals Act of 1910 recognised as Aboriginal «an aboriginal native of Australia or any of the islands adjacent or belonging thereto, or a half-caste who is living with an aboriginal as wife, husband or child, or a half-caste who, otherwise than as a wife, husband or child, habitually lives or associates with aboriginals or a half-caste whose age does not exceed 16 years ${ }^{21}$. In South Australia, the Aborigines Act (1911) defined a half-caste as «the offspring of an aboriginal mother and other than an aboriginal father» 22 .

Generated by the same paternalistic feeling which shaped the missions, the reserves and hostels were run either by Protectors or missionaries, and aimed at the protection and segregation of the Indigenous people ${ }^{23}$.

Hostels were established for young Aboriginal people whose parents lived and worked in cattle or pastoral stations, for children without parents and, more generally, for children who continued their studies ${ }^{24}$. They provided a shelter for them, but above all they cut off young Aboriginals from traditional family, forcing them to adapt to the Western system in order to be, gradually but inevitably, absorbed into White Australia. Full-blood fading away, the half-castes or partAborigines became «the big problem», the people to be looked after and integrated into the wider Australian population.

New policy concentrated on them, by taking them away from their parents during childhood; the subsequent intermarriage with Whites would guarantee their detribalisation. Making them whiter and whiter was the only way to elevate their social status and allowing them to become part of this «monolithic» White Australia ${ }^{25}$.

Large reserves were established everywhere, but especially in Northern Australia, mainly as a result of the pressure and requests of Protectors and Anthro-

19 Aborigines Protection Act (1886), Definitions.

20 Aboriginal Protection and Restriction of the Sale of Opium Act (I 897), Definitions.

21 Northern Territory Aboriginals Act (1910), Definitions.

22 Aborigines Act (1911), Definitions.

23 When speaking about these new settlements we should take into account that, although they were bureaucratically organised and managed, they were not so strictly defined, their management being either under Governments' staff or missionaries, who often interacted for the common cause. Also, what in New South Wales, for example, was regarded to as a station, was called a settlement or mission in Queensland. More generally, mission was the most widely used word, although sometimes quite improperly, as J.P.M. Long points out in defining such settlements: LoNG, Aboriginal Settlements ... [15], p. 3.

24 On distribution and figures of Aboriginal children in hostels, see SCHAPPER, Aboriginal Advancement to Integration ... [3], pp. 33-37.

25 ROWLEY, The Destruction of Aboriginal Society [9], p. 319 ff.; especially on the concept of a «monolithic» White Australia, see p. 332. 
pologists, who had begun to study Indigenous cultures, in an attempt to better understand the real needs of the Aboriginals.

Upon request of the Commonwealth - to which the control of the Northern Territory had just been handed over from South Australian Government ${ }^{26}$ - Sir Baldwin Spencer wrote a survey of the Aboriginal situation in 1912-1913, in which he extensively reported about the breakdown of the traditional Aboriginal system, provoked by the contact between Europeans, Asiatics and Aborigines. He submitted several suggestions and recommendations, and urged a general policy about Aboriginal Affairs to be managed directly by the Commonwealth. Baldwin Spencer, like A. P. Elkin and many other anthropologists after him, played an important role in, and greatly contributed to the creation, in one way or another, of the new Australian policy towards Aborigines. In fact, through their fieldworks, anthropologists could provide first hand information of the condition of life and also maintain relations with the Indigenous groups as well as with Protectors, Pastoralists, Missionaries and so on ${ }^{27}$.

Quoting some passages from Baldwin Spencer's report can be useful, and certainly interesting, to help to fully understand the actual situation:

«The half-castes are in a most unfortunate position ... No half-caste children should be allowed to remain in any native camp, but they should all be withdrawn and placed on stations. So far as practicable, this plan is now being adopted. In some cases, when the child is very young, it must of necessity be accompanied by its mother, but in other cases, even though it may seem cruel to separate the mother and child, it is better to do so, when the mother is living, as is usually the case, in a native camp ... A regulation should be passed forbidding them, except by special permit, to camp or wander about within the prescribed limits of any township between the hours of sunset and sunrise. Any aboriginal or half-caste infringing this regulation should be liable to be locked up by a police officer ... in view of the settlement of the country for which provision is now being made, there is no other practicable policy but that of the establishment of large reserves, if the aboriginals are to be preserved, and if

26 Northern Territory was managed by South Australian Government from 1863 to 1910 and passed under the control of the Commonwealth in 1911. We can see this date as the turning point of the policy adopted in this large territory. See LoNG, Aboriginal Settlements ... [15], p. 198.

27 While we have to appreciate the attempts of the anthropologists of that time towards the advancement of Aboriginals, we have also to recognise that quite often they lacked the necessary critical distance from the official administrators. Between them there was, rather, a sort of collaboration and good relations, which made it difficult to criticise, then, the work of management staff. Furthermore, being on good terms with government was a major requisite for an anthropologist to succeed in fieldwork and obtain grants. On this aspect of the relations between anthropologists and official agents, and especially the interaction between Prof. A.P. Elkin and Government, see G. GRAY, "Mr Neville did all in [his] power to assist me": A.P. Elkin, A.0. Neville and Anthropological Research in Northwest Western Australia 1927-1928», in Oceania, vol. 68, No 1, pp. 27-46 (Sydney, 1997).

R. I., 1999, n. $^{\circ} 217$ 
any serious effort is to be made for their betterment ... The primary object of all stations must be to train the natives in industrial habits. Until such time as they acquire these habits there is no chance whatever of raising them from their present condition ... The older natives must be kindly treated, rewarded for any work that they may do, and looked after in their old age ... it is of primary importance that the reserves should be retained for the use of the natives, with the idea of isolating them and preventing them from coming into contact with other people ${ }^{28}$.

And so it was.

The reserves established for Aboriginal people had, and some still have, no free access: that is exclusively under local government control. The government manager lived inside the reserve itself, keeping the residents under strict control. Schools and medical centres were set up to educate and assist those living inside, and, as in the tradition, blankets were distributed, with the usual warning not to sell or exchange them, because they remained «the property of His Majesty» ${ }^{29}$. Residents were also issued with rations, but these could be withheld as a punishment.

In 1920 the Commonwealth, together with the Governments of Western Australia and South Australia founded the «Central Australian Reserve». Between the 1920 's and 1930's many reserves were set up, like the huge Arnhem Land (Northern Territory). In East Kimberley (Western Australia), there were Moola Bulla, Marndoc and Violet Valley. Quite often, missions were established close to or inside the reserves themselves. In Arnhem Land, there were the mission on Bathurst Island run by Catholics, the Anglican one at Roper River, two set up by the Methodists (at Millingimbi and Goulbourn Island), and two by the Anglican Church Missionary Society (Groote Eylandt and Oenpelli). In the centre, close to Alice Springs, there was in the same period only the famous Hermannsburg, a Lutheran mission established at the beginning of this century. On the missions and reserves, Aboriginal people could be trained to work and, in some cases, they received a salary; marriage between Blacks and Whites was strictly forbidden, as well as consumption of alcohol, which is still forbidden on many former reserves.

Many Aborigines, rather than remaining on the missions (which did not really provide work opportunities), preferred to go to work on sheep and cattle stations, where they sometimes received a wage, although well below the normal

28 «20 May 1913. W. Baldwin Spencer's new policy», in STONE, Aborigines in White Australia ... [7], pp. 136-146 (emphasis in the text).

29 I. BRoOM \& F. LANCASTER JONES, A Blanket A Year (Aborigines in Australian Society, 10), Australian National University Press, Canberra, 1973, well explain the actual situation: all that the Aborigines receive in return for Australia is a blanket once a year. About the concept of blanket as a compensation for dispossession, see also RowLEY, The Destruction of Aboriginal Society ... [9], p. 233. 
one of the white employees ${ }^{30}$. In the stations established on northern lands of Western Australia, the wage was set by the station managers. In Kimberley for example, in 1967, Aboriginal wages were often so low that they did not even meet the minimum approved by the Wards Employement of Northern Territory ${ }^{31}$. In 1968, only the Aborigines who were members of the Australian Workers' Union received a proper wage. In Queensland, all working Aboriginal people received a wage, once again smaller than that of a non-Aboriginal, but enough to attract Aborigines from the closer regions, forced to choose quite often between unemployment and underemployment. In many stations, the work was of a seasonal type, due to climatic conditions. During «the wet», as the raining season is normally called in North Australia, Aborigines moved back to reserves and missions, to return to the stations when the work season had started again. Through seasonal movements, and once outside the missions, they had the possibility to reach the fringes of the cities and use the little money they had earned to buy tobacco and cheap wine, the fatal attraction of which remained strong over time. The seasonal work, along with the growing desire for European goods, greatly contributed to the origins of the so-called fringe-dwellers, Aboriginal people living at the fringe of Australian cities and towns, whose very miserable camps constitute a further example of settlement generated by the contact with White culture, which is still a sad reality in some places ${ }^{32}$.

\section{ASSIMILATION POLICY}

In 1937, Commonwealth Government convened a conference on Aboriginal affairs with Australian States and it was agreed that the natives of Indigenous ancestry, excluding full-blood, should be assimilated into wider Australia through gradual insertion into economic and social life. For the full-blood the only solution contemplated in this context was segregation into reserves, in which they were left to die out ${ }^{33}$.

30 On Aboriginal employment and wages, see the extensive analysis by C.D. RowLEY in his chapter «Wages and Conditions of Employment in the 'Colonial' Regions», 'in The Remote Aborigines (Aboriginal Policy and Practice, vol. III) (Aborigines in Australian Society, 7), Australian National University Press, Canberra, 1970, pp. 217-348.

31 For a full account about Aboriginal work in Northern Territory cattle stations, see F. STEVEnS, Aborigines in the Northern Territory Cattle Industry (Aborigines in Australian Society, 11), Australian National University Press, Canberra, 1974. He visited Aboriginal stations camps in 1965 and again in 1967.

32 They have been called the «legion of the lost» by Neville T. BONNER A.O. in his opening address «Aratjara», in D. RIEMENSCHNEIDER \& G.V. DAVIS (eds.), Aratjara. Aboriginal Culture and Literature in Australia, Rodopi, Amsterdam \& Atlanta, 1997, p. 3 ff.

33 See Rowley, The Destruction of Aboriginal Society [9], especially pp. 136-139, 286-287, and p. $320 \mathrm{ff}$.

\section{R. I., $1999, \mathrm{n}^{\circ} 217$}


A few years later, in 1944, the Western Australia Native (Citizenship Rights) Act set out the terms for granting a Certificate of Citizenship to Aborigines. Apart from the fact that Aevery application shall be accompanied by two recent written references from reputable citizens certifying as to the good character and industrious habits of the applicant», an Aboriginal person could obtain the certificate provided that «for the two years immediately prior ... [he/she] has adopted the manner and habits of civilised life ..., is able to speak and understand the English language, ... is not suffering from active leprosy, syphilis, granuloma and yaws». And further below, «Upon complaint of the Commissioner of Native Affairs or any other person», a magistrate may cancel the Certificate any time, and, if one of the above requisites failed to be present, the citizen manque would be demoted again to a native ${ }^{34}$. As we can see, the Aboriginal right to retain customs and language, for instance, was totally ignored. Furthermore, proving to be in good health and not suffering from any of the four listed diseases (all of them imported by Whites) was hardly possible for Aborigines, because in the conditions in which they were forced to live at that time, these diseases were endemic.

These were the years of World War II, the effects of which greatly influenced social changes in Australia, especially in Northern Territory. In fact, due partly to the shortage of white labour caused by the war and partly to the better conditions offered, many Aborigines were army employees.

The research by the anthropologists Ronald and Catherine Berndt -commissioned in 1945 by Vesteys, one of the biggest pastoral companies- well describes the living conditions of Aboriginals both in pastoral stations and in army camps $^{35}$. In the former, the Berndts found that Aboriginal men were employed as stockmen, gardeners, wood choppers, and assistants to saddler, carpenter and cook, while women milked cows, washed, ironed, cleaned the house, sewed and helped in various ways. The general living conditions were really miserable: there were no sanitary facilities, no safe drinkable water, poor shelters, and the only food available consisted normally of dry bread, a piece of beef and sweetened tea. Instead, the army camps visited by the Berndts offered far better conditions: good food, tobacco and clothing for everybody, proper facilities, laundries, a friendly treatment, medical attention and canteens, where the Aboriginals were allowed to enter and even to spend the money they earned in sweets, if they so wished.

34 «1944. A Certificate of Citizenship», in STONE, Aborigines in White Australia... [7], pp. 184-185 (my emphasis). It is amazing the fact that, speaking about Citizen Rights, the initial of the word Aborigine and the like are always written in small letters, while Australia and the like are always written in capital letters, as it should be in the context of English language, where geographical names and titles related to nationality (among others) are always written so. We shall have to wait until the 1960's to see a change in this attitude.

35 See F. Stevens, The Politics of Prejudice, Alternative Publishing Co-operative Ltd., Sydney, 1980, p. 49 ff., and ROWLEY, The Destruction of Aboriginal Society [9], p. $332 \mathrm{ff}$.

R. I., $1999, \mathrm{n}^{\circ} 217$ 
The contrast between the two situations, above all the cash wage paid to the Aborigines by the Army, whereas in the stations they received none, strongly contributed to stress the urgent need for equal opportunities and justice.

Dispossession of land, very little improvement of health services, some education and training programs, underpaid work, poor shelters, Christianism, disintegration of the traditional system and loss of identity: this was what White Australia offered to Aborigines - as British subjects - through the assimilation policy. In sharp contrast are the statements by the Minister for Territories, Mr. Hasluck, who, in 1951, described the policy of assimilation as follows:

«Assimilation does not mean the suppression of the aboriginal culture but rather that, for generation after generation, cultural adjustment will take place. The native people will grow into the society in which, by force of history they are bound to live ... It is a policy of opportunity. It gives to the aboriginal and to the person of mixed blood a chance to shape his own life. If he succeeds, it places no limit on his success but opens the door fully» ${ }^{36}$.

The relationship between White and Black Australians sensibly, though slowly, changed, and Aborigines were entitled to a more respectful treatment. In the following years, social services were improved, and education and training programmes were developed.

By the 1960's, the Aboriginal population could be divided into two main groups, the one composed of Indigenous groups mainly living in reserves, with some following their traditional way of life - those supposed to have died out, who, against all odds and thanks to the inviolable reserves, were increasing in number - and that of the part-Aborigines or halfcastes, which included both people who were trying to integrate themselves into wider society and the fringe$d w e l l e r s$ the last being those who mostly experienced the disastrous effects of the contact with White Culture ${ }^{37}$.

\footnotetext{
36 «18 October 1951. Mr. Hasluck's report on the Native Welfare Conference», in STONE, Aborigines in White Australia ... [7], pp. 193-197 (the extract is at p. 197).

37 We can identify a fourth and more recent kind of Aboriginal settlement, generated by the movement to get back to traditional countries -called «outstation movement» by White Australians and «country camp movement» by Aboriginals. Family groups in remote parts of Australia, in an attempt to restore their identity and re-establish their close relation with land (by all means), have set up camps in which they live as hunter-gatherers of the 20th century. Basic necessities are provided by the Government, such as water tanks and houses, while social and cultural life is guaranteed through painting and education of the children in respect to tribal lore. Hunting and traditional ceremonies are practiced anew.

This attempt, over the years, turned out to be a success and it led to important consequences, both in land and social rights, although health, water and transport facilities, among others, are still inadequate in some places. No entry is allowed without permission and alcohol is banned, but now by their own choice. Furthermore, paintings and handicrafts produced inside the camps are sold to get money
} 
The two censusses of 1961 and 1966 are of particular importance in our analysis, since the definitions of Aboriginal full-blood and half-caste - those in need of care - prove to be a useful key to understanding the changing attitudes of European Australia towards Aboriginals ${ }^{38}$ :

«For persons of European race, wherever born, write 'European'. For nonEuropeans state the race to which they belong, for example, 'Aboriginal', 'Chinese', 'Negro', 'Afghan', etc. If the person is half-caste with one parent of European race, write also 'H.C.', for example 'H.C. Aboriginal', 'H.C. Chinese', etc.»

These were the instructions of the 1961 Census, which declared, through their own words, a person of mixed Aborigine/non-European ancestry as an Aboriginal full-blood, having the half-caste necessarily one parent of European race. This shows a clear interest in knowing and stressing the European origin, whereas an origin other than European was merely neglected.

According to the results, 75.309 people claimed to be Aboriginals, of whom 36.137 were full-blood, and 39.172 half-caste ${ }^{39}$.

In analysing the figures of this census we have to take into account that, for Aboriginal people, stating their own race depended on the way in which they regarded the definitions of full-blood and half-caste. For instance, many partAborigines would describe themselves as Aborigines, because they reject the term half-caste, others living at the fringe of the cities and particularly attracted by the European life-style would associate themselves to Europeans, identifying in this case race with social status, and showing the desire for what they would like to be, rather than what they are. On the other side, part-Aboriginal people could claim their tribal ancestry by electing 'Aboriginal' as a reply, rather than 'H.C.', misstating, as a consequence, the reality. Finally, and because of the ambiguity of the question, part-Aborigines, with both parents of part-Aboriginal origins, would have real trouble in defining themselves as full-blood or as Europeans.

The 1966 Census, in an attempt to provide a better stratification of the population, read as follows:

for the community. At mid-1981, there were 165 homeland centres. Among the publications on this subject, see D. Leichleitner JaPANANGKa \& P. NATHAn, Settle Down Country - Pmere Arlaltyewele, Kibble Books \& Central Australian Aboriginal Congress, Malmsbury \& Alice Springs, 1983.

38 I have based this part of the article on the survey by LANCASTER JONES, The Structure and Growth [14], and on RowleY, The Destruction of Aboriginal Society [9], Appendices A and B.

39 To these figures, we have to add almost 4.000 «out of contact» Aborigines, of whom 2.000 settled in Western Australia and 1.944 in Northern Territory, according to the authorities of that time. This would bring a final total of 79.253. Instead, according to J.P.M. Long, traditional Aborigines were at that time less than 500 people; the official figures provided were, therefore, largely overestimated. Quoted in RowLEY, The Destruction of Aboriginal Society [9], p. 366.

R. I., $1999, \mathrm{n}^{\circ} 217$ 
«State each person's race. For persons of European race, wherever born, write 'European'. Otherwise state whether Aboriginal, Chinese, Indian, Japanese, etc., as the case may be. If of more than one race give particulars, for example, 1/2 European-1/2 Aboriginal, 3/4 Aboriginal-1/4 Chinese, 1/2 European-1/2 Chinese».

I believe that giving a definite answer to this question would be a challenge for anybody!

According to these instructions, people defining themselves as 3/4 Aboriginal-1/4 European (therefore, more than half-Aboriginal) would fall in the fullblood group, whereas in the 1961 Census they would have been considered as 'H.C. Aboriginal': the direct consequence of such a classification is an incredible increase of full-blood. Vice versa, a person regarding himself/herself as 1/4 Aboriginal-3/4 European would be considered as European. According to this Census, a half-caste is now a person with exactly $1 / 2$ Aboriginal and 1/2 European origins; predominant percentages of one of the two breeds would lead inevitably to include him/her either within the full-blood or within the European group. In 1967 , one year after and already out-of-date, the results were released (this delay being due to the extreme difficulty in elaborating them): 79.620 people were defined as Aboriginals, regardless of their percentage of ancestry ${ }^{40}$.

It is difficult comparing the results of the two censes, due to the difference provoked by their respective phrasings and by the unreliability of the answers. What is undeniable, however, is their common background: they both tended towards whiteness, and prejudice with regard to colour of skin played a prominent part in legislating for Aboriginal Affairs.

We could stress the fact that, according to these results, the Aboriginal population increased by only 367 people, during these 5 years, which seems to be not reasonable. Of course, the oddness is only apparent: we can suppose, in fact, that many part-Aborigines, stating that they were 1/4 Aboriginal-3/4 European, diminished in this way the Aboriginal percentage; in so doing, they were considered as Europeans and, as a consequence, were excluded from the count.

Even from this short account, we can infer that defining and establishing the exact number of persons belonging to a minority group is not an easy task. In this specific case, besides, members belonging to this minority were registered nowhere and lived, and some still live, scattered throughout the continent; they tended to move from a place to another, thereby shifting from countries to towns

40 In this case we have not anymore the distinction between full-blood and half-caste because, if we did so, the statement of the facts would be even less reliable. Being racial definitions so strict and far from being representative of the real situation, if we split the figures in order to stress the half-half population, we would not succeed in knowing the real state of affairs, scientifically demonstrable.

R. I., 1999, n. ${ }^{\circ} 217$ 
and cities, at times leaving a State and entering into another. If, to all this, we add the difficulties generated by the understanding of a bureaucratic question like that one of a census, and in a foreign language, we could conclude that these results, though important, represent rather estimated figures of the trend of the Indigenous migration and distribution.

\section{TOWARDS AN INTEGRATION POLICY}

Assimilation policy - which proved to be ineffective - went under strong criticism by concerned citizens and also by the many institutions created just for the achievement of Aboriginal welfare. This led to a policy of integration, where respect of the Indigenous cultures and recognition of their rights if not fully applied, became more accepted or, at least, more acceptable, even though, as we shall see, discrimination was still strong and a genuine intention to improve their quality of life was far from being present. Aborigines became more and more concerned about their rights, and as a result leagues and associations were formed among those living closer to White society, speaking out also on behalf of the more isolated Indigenous groups.

At the end of the 1960's, the need for a real, genuine policy to promote Aboriginal advancement had become more than urgent. Each State continued to legislate on Aboriginal Affairs on its own, which brought many problems, mainly due to the Aboriginal high mobility within the continent. Australian citizens, as well as the Aboriginal Advancement Movement urged that the Australian Constitution be amended, to bring the Aboriginal Affairs of each State all under Commonwealth's control.

On 27 May 1967, through the Constitutional Alteration (Aboriginals) Referendum, an overwhelming majority of Australians (91\%) empowered the Commonwealth to legislate in Aboriginal Affairs. This meant, above all, that Aborigines were, finally, recognised as Australian citizens, and officially entitled to vote. In time, new policies on Aboriginal Land Rights were announced, Departments and Commissions were established to develop federal policies: the achievement of Aboriginal welfare became the major objective of the new legislation.

In March 1971, the representatives of the Victorian Aborigines Advancement League $^{41}$ pointed out to the United Nations the right of Aboriginal people to be recognized as the owners of Australian land. We quote here few passages of this amazingly sharp outline:

41 About this League, which, since 1957, is the voice of all the Koories, the Aborigines of Victoria, see Victims or Victors? The Story of The Victorian Aborigines Advancement League, by Victorian Aborigines Advancement League, Hyland House, South Yarra, 1985.

R. I., $1999, \mathrm{n}^{\circ} 217$ 
«We make this plea under Item 55 of the General Assembly, which deals with the elimination of all racial discrimination; for it is only racial discrimination which can explain the refusal of the Government of Australia to grant us, and us alone, our rights ... FROM THE TIME OF THE FIRST SETTLEMENT IN 1788 TO DATE, THE CROWN HAS NEVER USED EVEN ITS CLAIMED POWER TO TAKE OUR LAND EITHER BY TREATY OR BY PURCHASE. THE CROWN HAS BLATANTLY TAKEN OUR LAND WITHOUT TREATY, WITHOUT PURCHASE AND WITHOUT COMPENSATION OF ANY KIND ... We, the Aborigines of Australia whom the invaders have not yet succeded in wiping off the face of the earth, are the owners of the land of Australia in equity, in the eyes of any system of civilized law and in justice and yet we have no share in the great mineral, agricultural and pastoral wealth of our country...» ${ }^{42}$.

A few months later, Mr. Len King, the then South Australian Minister for Aboriginal Affairs, described a new Aboriginal policy of integration, aimed to encourage self-management in Aboriginal Affairs, to improve their economy, health, housing, employment and education, and to eliminate all discriminative provisions: I look to the day when Aborigines will take their place in the political parties, in general organisations of the community, and will seek and attain political office ${ }^{43}$.

For the completion of the information, we report the 1971 Census question:

«What is this person's racial origin?

(If of mixed origin indicate the one to which he considers himself to belong).

(Tick one box or give one origin only)

- European origin

- Aboriginal origin

- Torres Strait Islander origin

- Other origin (give one only) $)^{44}$.

42 «18 March 1971. Aborigines' communication to the United Nations», in STONE, Aboriginal in White Australia.. [7], pp. 230-231 (emphasis in the text).

43 «15 September 1971. The Shaping of a New Aboriginal Policy in South Australia», in STONE, Aboriginal in White Australia.. [7], pp. 231-235 (the passage quoted is at p. 235).

44 See the Official Year Book Australia, n. 59, 1973, Australian Bureau of Statistics, Canberra, p. 143. As for the results, 106.288 persons stated themselves to be of Aboriginal origins. In addition, 9.663 persons identified themselves as Torres Strait Islanders, making a total of 115.951 (see p. 417). By 1991 the census showed an indigenous population of 265.000 , representing $1,6 \%$ of the total Australian population.

R. I., $1999, \mathrm{n}^{\circ} 217$ 


\section{EPILOGUE}

Over the last 20 years, the concepts of self-management and self-determination have taken the place of assimilation and integration, shaping the present Australian society.

These concepts - while recognising in words increased rights for Aboriginal people than in the past, and acknowledging that they must be involved in programmes, develop initiatives and take decisions autonomously- continue in daily practice to fail in this attempt and, even worse, they perpetuate Aborigines' state of dependency ${ }^{45}$.

In spite of the several Land Right Acts and the countless Aboriginal claims for lands, it was only on 3 June 1992 that Australia's definition of Terra Nullius was officially rejected. Eddie Mabo and four other Meriam people claimed that Murray Island - and surrounding islands and reefs - had been inhabited and possessed since time immemorial by the Meriam people. In upholding the Islanders' claim, the High Court held that Australia, when settled in 1788 by the British, was not a no one's land, but it was occupied by Aborigines ${ }^{46}$. The official recognition of native title and, consequently, of the whole Aboriginal system of laws and customs, has brought to light a certain number of still unsolved, but crucial issues, such as which areas of land are subject to native title, if and where native title can co-exist with other interests in the same land, and, of special importance, definition of compensation for dispossession ${ }^{47}$. This last seems to raise particular problems, due to the gap between Indigenous and non-Indigenous concepts of property, law and, most importantly, value to be attributed to the land. The special, unique relationship between Aborigines and land, as we have seen, involves both material and spiritual links, the latter being difficult, if at all possible, to be calculated within the Western intellectual frame. It will take time to arrive at an agreement, but perhaps faults made in the past can be of some help.

45 For an «ethnographic exploration» (to quote author's words) of the policy of Aboriginal selfdetermination, see the recent article by G. COWLISHAW, «Erasing Culture and Race: Practising 'self-determination'», in Oceania, vol. 68, No 3, pp. 145-169 (Sydney, 1998).

46 See: MABO, Outline of Proposed Legislation on Native Title, Commonwealth of Australia, Canberra, September 1993. On the consequences and possible developments of the «Mabo case», see, among others: T. RowSE, After Mabo. Interpreting indigenous traditions, Melbourne University Press, Melbourne, 1993.

47 Further to the «Mabo decision», the payment of compensation is a principal issue, the many facets of which are currently discussed, studied and evaluated. The Native Title Research Unit of the Australian Institute of Aboriginal and Torres Strait Islander Studies has recently devoted to this topic a series of short, but thorough articles; I am referring, in particular, to: J.C. ALTMAN, Compensation for Native Title: Land Rights Lessons for an Effective and Fair Regime (Issues paper, 20, April 1998); M. LAVARCH \& A. RIDING, A New Way of Compensating: Maintenance of Culture through Agreement (Issues paper, 21, April 1998); K. MUIR, «This Earth Has an Aboriginal Culture Inside». Recognising the Cultural Value of Country (Issues paper, 23, July 1998). 
In fact, if it is impossible to obliterate all the past errors, it might be possible, through their admission and deep analysis, to digest them and, once part of the common memory, to use them as a tool to avoid further errors in the future. If little progress has been done in this sense till now, perhaps it is because learning to understand and to honestly and genuinely accept the other's mind, without prejudices, needs a certain mental exercise and will.

\section{AKNOWLEDGEMENTS}

I am particularly grateful to Dr. Mónica Quijada (CSIC-Centro de Estudios Históricos, Madrid) for having invited me to contribute to this issue of Revista de Indias.

I am especially grateful to Alex Barlow, BA LLB MA (Australian InFo International, Canberra) for his careful reading of this text. As always, I have greatly benefited from his advice as a specialist of Aboriginal History and Culture.

I would like to extend my general thanks to the Native Title Research Unit of the Australian Institute of Aboriginal and Torres Strait Islander Studies (AIATSIS, Canberra) for providing me with useful and updated documentation, and to the Australian Embassy in Rome, in the person of Mrs. Mara Mele, who, once again and with her usual kindness, facilitated my access to the documentation of the Library.

Any remaining errors are of course my own.

The purpose of this paper is to provide an account of the contact/impact between Aborigines and Europeans, generated by the coming of the British First Fleet to Australia in 1770, and the further European Settlement. It will outline the changing attitudes of White Australians towards Aboriginal Australians, passing from the initial violence of the colonisation, to the paternalism and protective feeling which characterized the first years of this century. It will then define the policy of forcible assimilation and that of integration, which shaped the years between the 1940's and the end of the 1970's.

R. I., $1999, \mathrm{n}^{\circ} 217$ 